\title{
Mineralogical analysis of bronchoalveolar lavage fluid as an aid to diagnosis of "imported" pleural asbestosis
}

\author{
P DE VUYST, M MAIRESSE, A GAUDICHET, P DUMORTIER, J JEDWAB, \\ JC YERNAULT
}

From the Service de Pneumologie, Hôpital Erasme, and the Laboratoire de Géochimie, Université Libre de Bruxelles, Brussels; the Département de Pneumologie, Clinique Saint-Luc, Bouge, Belgium; and the Laboratoire d'Etude des Particules Inhalées, Direction des Affaires Sanitaires et Sociales, Paris

Benign and malignant pleural disease can be related to the inhalation of asbestos fibres resulting from occupational exposure. In some areas of the world (notably Corsica, Canada, and Turkey), however, there is a nonoccupational hazard because asbestos fibres are present in the soil. We report an "imported" case of pleural disease related to non-occupational asbestos exposure in which the diagnosis was established by bronchoalveolar lavage.

\section{Case report}

A 57-year-old Turkish woman was referred for investigation of bilateral pleural thickening. She had been born in Karakalar in the Afyon area of Anatolia and had lived in Belgium for 23 years. She had never worked and had no past history of smoking or respiratory disease.

There were no remarkable respiratory symptoms and physical examination showed nothing abnormal. The chest radiograph showed bilateral nodular pleural thickening with diaphragmatic calcification. There was no evidence of pleural fluid. Results of laboratory studies, including estimation of arterial blood gases, were all within normal limits. Fibreoptic bronchoscopy showed no tracheobronchial lesions. Tests of lung function showed a mild obstructive ventilatory defect and a normal gas-transfer factor.

An open pleural biopsy was performed, which showed hyaline plaques on the parietal pleura. Histological examination showed that the plaques consisted of avascular hyalinised connective tissue, with a few fibroblasts. There were no signs of malignancy (mesothelioma) or of asbestos fibres.

Bronchoalveolar lavage was performed during the fibreoptic bronchoscopy and mineralogical analysis of the lavage fluid was carried out. A sample of the fluid $(25 \mathrm{ml})$ was bleach digested, filtered on membrane filters (porosity $0.45 \mathrm{~mm}$ ), and studied under an optical microscope. ${ }^{1}$ Typical asbestos bodies were found in large numbers (117 per $\mathrm{ml}$ of fluid). They all showed the classical shape with a regularly segmented ferroprotein coating. ${ }^{2}$ Pieces of the membrane filters were studied under a transmission electron microscope fitted with an $x$-ray energy-dispersive

Address for reprint requests: Dr $P$ De Vuyst, Service de Pneumologie, Hôpital Erasme, Université Libre de Bruxelles, Brussels, Belgium.

Accepted 10 January 1983. spectrometer (EDS). ${ }^{3}$ This allowed us to perform elementary chemical analysis of the central core of the ferruginous bodies (fig 1) and also of some uncoated fibres (fig 2). ${ }^{\infty}$

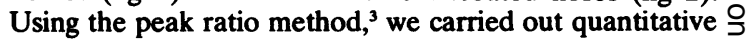
treatment of the raw EDS spectra to express the weight percentage of oxides for each analysed fibre. The fibres were identified as tremolite asbestos $\left(\mathrm{MgO} 21 \%, \mathrm{SiO}_{2}\right.$ 틀 $52 \%, \mathrm{CaO} 16 \%, \mathrm{FeO} 10 \%$ ). No erionite (zeolite) was $\frac{\bar{\omega}}{\omega}$ found among the fibrous silicates. ${ }^{4}$

\section{Discussion}

Pleural thickening with calcification, without clinical or histological evidence of tuberculosis, is highly suggestive of benign pleural asbestosis. This rarely causes respiratory symptoms or severe alterations of lung function. ${ }^{5}$ In this

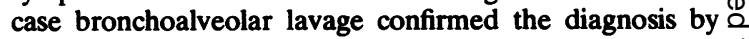
disclosing a very considerable number of asbestos bodies, $\overrightarrow{\vec{O}}$ representing an important alveolar load. In our experi- 3 ence, ${ }^{1}$ such a result has been found only in people with definite exposure to asbestos and with pleural or parenchymal asbestosis.

Pleural asbestos-related disease (benign or malignant) can occur in people with no direct occupational contact with asbestos as a result of domestic exposure (family members of asbestos workers bringing their clothes home), neighbourhood exposure (residence near an asbestos factory), or environmental exposure. 5 Some rural areas of $\delta$ Turkey (Anatolia) are zones of endemic pleural disease owing to the presence of asbestiform minerals in the soil. ${ }^{6} \mathrm{O}$ Tremolite asbestos is geologically present in the zones around Afyon, where studies have shown pleural disease in $6-25 \%$ of the general population. ${ }^{6}$ People are exposed from their youth because the local asbestos-containing $N$ material is used for home construction and to whitewash the dwellings, and women usually prepare the mixtures for wall covering. ${ }^{78}$

This work was supported by grant 3.4517 .82 from the Fonds de la Recherche Scientifique Médicale.

\section{References}

${ }^{1}$ De Vuyst P, Jedwab J, Dumortier P, Vandermoten G, Vande $\frac{\Omega}{\Phi}$ Weyer R, Yernault JC. Asbestos bodies in broncho-alveolar 0 lavage. Am Rev Respir Dis 1982;126:972-6. 


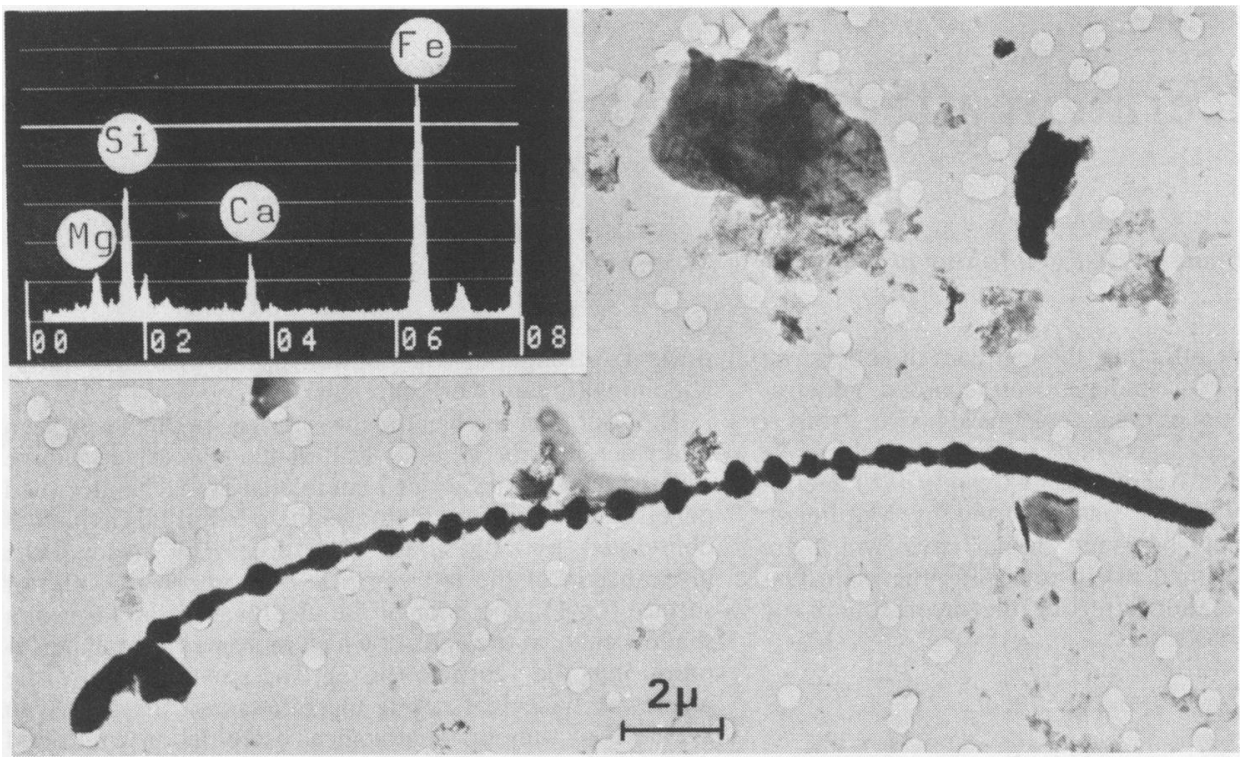

Fig 1 Ferroproteincoated tremolite fibre (asbestos body); spectrum typical of energy-dispersive spectrometry (EDS) shows higher peaks of iron owing to the coating.
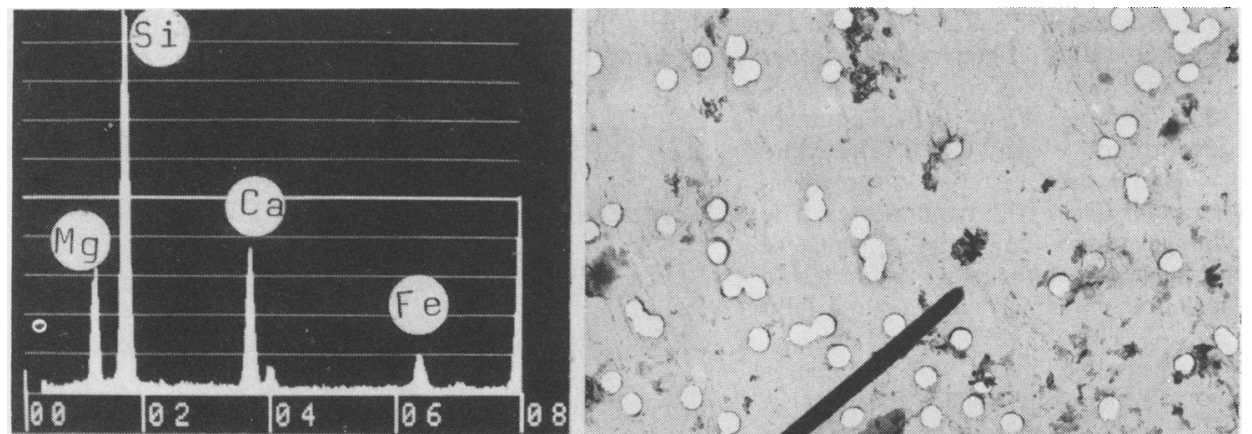

Fig 2 Uncoated tremolite fibre with typical EDS spectrum.

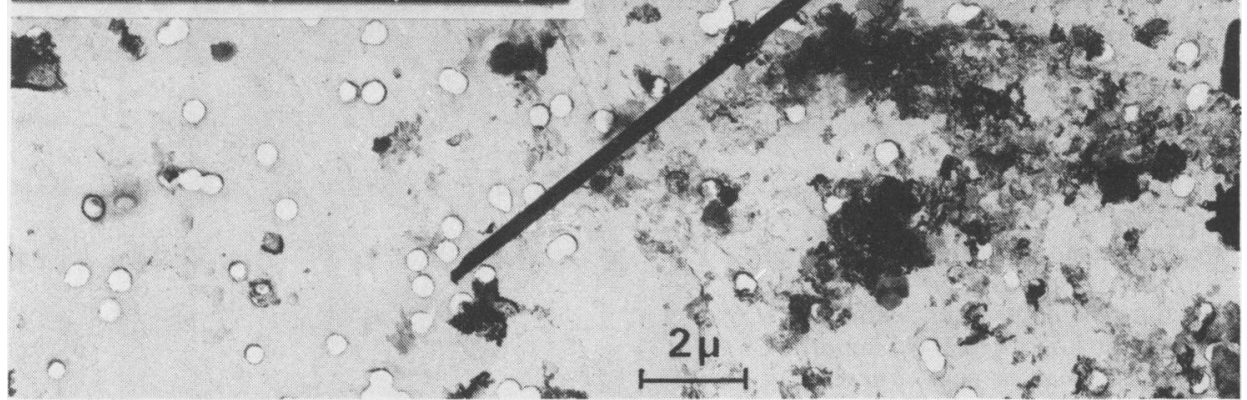

${ }^{2}$ Pooley FD. Asbestos bodies, their formation, composition and characters. Environ Res 1972;5:363-79.

${ }^{3}$ Sebastien P, Billon MA, Janson X, Bonnaud G, Bignon J. Utilisation du microscope électronique à transmission (MET) pour la mesure des contaminations par l'amiante. Archives des Maladies Professionnelles, de Médecine du Travail et de Sécurite Sociale 1978;39:229-48.

4 Sebastien P, Gaudichet A, Bignon J, Baris Y. Zeolite bodies in human lungs from Turkey. Lab Invest 1981;44:420-5.

${ }^{5}$ Becklake M. Asbestos-related diseases of the lung and other organs: their epidemiology and implications for clinical prac- tice. State of the art. Am Rev Respir Dis 1976;114:187-227.

- Baris I, Artvinli M, Sahin A, Savas T, Erkan M. Etude du mésotheliome pleural malin, de la pleurésie fibrosante chronique et des plaques pleurales liees à l'environnement en Turquie. Rev Fr Mal Respir 1979;7:687-94.

' Yazicioglu S, Ilcayto R, Balci K, Sayli B, Yorulmaz B. Pleural calcification, pleural mesotheliomas and bronchial cancers caused by tremolite dust. Thorax 1980;35:564-9.

- Baris Y, Sahin A, Ozesmi M, et al. An outbreak of pleural mesothelioma and chronic fibrosing pleurisy in the village of Karain/Urgup in Anatolia. Thorax 1978;33:181-92. 